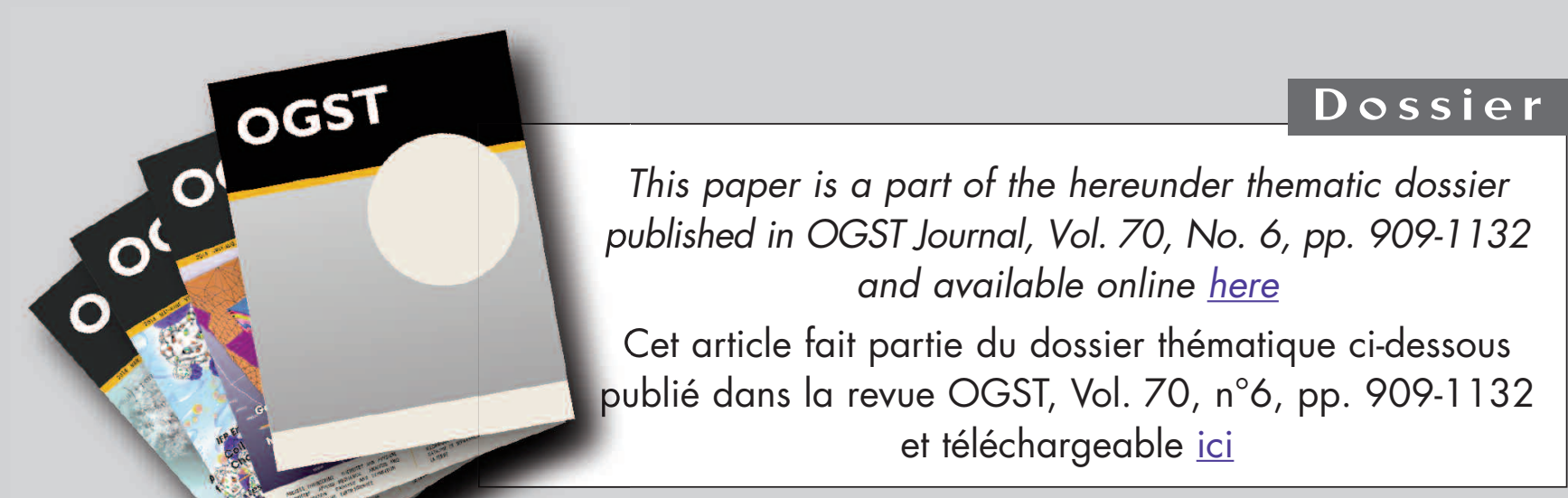

Oil \& Gas Science and Technology - Rev. IFP Energies nouvelles, Vol. 70 (2015), No. 6, pp. 909-1132

Copyright (C) 2015, IFP Energies nouvelles

909 > Editorial - Enhanced Oil Recovery (EOR), Asphaltenes and Hydrates Éditorial - EOR «récupération assistée du pétrole», Asphaltènes et Hydrates D. Langevin and F. Baudin

\section{ENHANCED OIL RECOVERY (EOR)}

917 > HP-HT Drilling Mud Based on Environmently-Friendly Fluorinated Chemicals Boues de forage HP/HT à base de composés fluorés respectueux de I'environnement

I. Henaut, D. Pasquier, S. Rovinetti and B. Espagne

931 > Effective Viscosity in Porous Media and Applicable Limitations for Polymer Flooding of an Associative Polymer

Viscosité effective dans des médias poreux et limites d'application de l'injection de polymères associatifs

P. Zhang, Y. Wang, Y. Yang, W. Chen and S. Bai

$941>$ Dynamic Gelation of HPAM/Cr(III) under Shear in an Agitator and Porous Media Gélification dynamique de HPAM/Cr(III) sous cisaillement dans un agitateur et en milieu poreux

Y. Haiyang, W. Yefei, Z. Jian, L. Peng and S. Shenglong

$951>$ Computer Modeling of the Displacement Behavior of Carbon Dioxide in Undersaturated Oil Reservoirs

Modélisation par ordinateur du comportement de déplacement du dioxyde de carbone dans des réservoirs d'huile non saturés

B. Ju, Y.S. Wu and J. Qin

$967>$ Predicting CO, Minimum Miscibility Pressure (MMP) Using Alternating Conditional Expectation (ACE) Algorithm

Prédiction de la pression miscibilité minimum (MMP) du CO en utilisant un algorithme basé sur l'ACE (Alternating Conditional Expectation)

0 . Alomair, A. Malallah, A. Elsharkawy and M. Iqbal

983 > Towards the Development of Bitumen Carbonates: An Integrated Analysis of Grosmont Steam Pilots

Vers le développement des carbonates bitumineux : une analyse intégrée des pilotes vapeur de Grosmont

C.C. Ezeuko, J. Wang, M.S. Kallos and I.D. Gates

1007> A Novel Model of Foam Flooding Considering Multi-Factors for Enhancing Oil Recovery

Un nouveau modèle d'injection de mousse considérant de multiples facteurs afin d'améliorer la récupération de pétrole

J. Wang, H. Liu, H. Zhang, G. Zhang, P. Liu and K. Sepehrnoori
1025> Testing of Snorre Field Foam Assisted Water Alternating Gas (FAWAG) Performance in New Foam Screening Model

Vérification des performances de la méthode FAWAG (Foam Assisted Water Alternating Gas) sur le champ de Snorre, en Norvège, avec un nouveau modèle de sélection des mousses

P. Spirov and S. Rudyk

\section{ASPHALTENES}

1035> Structural Study of Asphaltenes from Iranian Heavy Crude Oil Étude structurale d'asphaltènes de pétrole brut lourd iranien L. Davarpanah, F. Vahabzadeh and A. Dermanaki

$1051>$ Experimental Study and Mathematical Modeling of Asphaltene Deposition Mechanism in Core Samples

Étude expérimentale et modélisation mathématique du mécanisme de déposition d'asphaltène dans des carottes de forage

T. Jafari Behbahani, C. Ghotbi, V. Taghikhani and A. Shahrabadi

1075> Prediction of the Gas Injection Effect on the Asphaltene Phase Envelope Prévision Prévision de l'effet d'injection de gaz sur l'enveloppe de phase des asphaltènes P. Bahrami, R. Kharrat, S. Mahdavi and H. Firoozinia

\section{HYDRATES}

1087> Methane Hydrate Formation and Dissociation in the Presence of Silica Sand and Bentonite Clay

Formation et dissociation d'hydrates de méthane en présence de sable de silice et d'argile de bentonite

V. Kumar Saw, G. Udayabhanu, A. Mandal and S. Laik

$1101>$ Prediction of Mass Flow Rate in Supersonic Natural Gas Processing Prédiction du débit massique dans les applications de traitement supersonique du gaz naturel

C. Wen, X. Cao, Y. Yang and Y. Feng

$1111>$ Experimental Study on Hydrate Induction Time of Gas-Saturated Water-in-Oil Emulsion using a High-Pressure Flow Loop

Étude expérimentale sur le temps d'induction d'hydrate d'une émulsion eau-enhuile saturée en gaz en utilisant une boucle à circulation sous haute pression X.F. Lv, B.H. Shi, Y. Wang, Y.X. Tang, L.Y. Wang and J. Gong

1125> Hollow Silica: A Novel Material for Methane Storage La silice creuse : un nouveau matériau pour le stockage de méthane V.D. Chari, P.S.R. Prasad and S.R. Murthy 


\title{
HP-HT Drilling Mud Based on Environmently-Friendly Fluorinated Chemicals
}

\author{
I. Henaut ${ }^{1 *}$, D. Pasquier ${ }^{1}$, S. Rovinetti ${ }^{2}$ and B. Espagne ${ }^{3}$ \\ ${ }^{1}$ IFP Energies nouvelles, 1-4 avenue de Bois-Préau, 92852 Rueil-Malmaison Cedex - France \\ 2 Solvay Specialty Polymers Italy, Viale Lombardia, 20 - 20021 Bollate - Italy \\ ${ }^{3}$ Total, avenue Larribau, 64018 Pau Cedex - France \\ e-mail: isabelle.henaut@ifpenergiesnouvelles.fr \\ * Corresponding author
}

\begin{abstract}
The worldwide growing demand for energy drives oil and gas companies to drill deeper and hotter wells. The exploration and the development of Deeply Buried Reservoirs (DBR) generate major technical challenges due to the extremely high pressures and temperatures met (1 $\left.400 \mathrm{bar}, 300^{\circ} \mathrm{C}\right)$. Currently, several drilling fluids are emerging. They are briefly reviewed at the beginning of the paper. The technical difficulty related to HP-HT mud is so significant that standard mud formulation technologies are irrelevant and alternative systems have to be considered. New formulations based on perfluorochemicals have been jointly developed by IFP Energies nouvelles (IFPEN), Solvay Specialty Polymers Italy and Total. Their lab characterizations are presented and reveal their promising benefits.
\end{abstract}

Résumé - Boues de forage HP/HT à base de composés fluorés respectueux de l'environnement — La demande croissante en énergie pousse les entreprises pétrolières et gazières à forer de plus en plus profond. L'exploration et l'exploitation des gisements très enfouis (Deeply Buried Reservoirs, DBR) génèrent des défis techniques importants en raison des pressions extrêmement élevées et des températures rencontrées $\left(1400 \mathrm{bar}, 300{ }^{\circ} \mathrm{C}\right)$. Actuellement, plusieurs fluides de forage sont mis sur le marché. Ils sont brièvement passés en revue au début du manuscrit. La difficulté technique liée à la boue HP-HT est telle que les technologies habituelles de formulation de boues sont inadaptées et des systèmes alternatifs doivent être considérés. De nouvelles formulations à base de composés perfluorés ont été développées conjointement par IFP Energies nouvelles (IFPEN), Solvay Specialty Polymers Italy et Total. Leurs caractérisations en laboratoire sont présentées et montrent leur potentiel. 


\section{INTRODUCTION}

The worldwide growing demand for energy drives oil and gas companies to drill deeper and hotter wells. The exploration and the development of Deeply Buried Reservoirs (DBR) generate major technical challenges due to the extremely high pressures and temperatures met (1400 bar, $300^{\circ} \mathrm{C}$ ). Such severe conditions demand careful attention to select efficient mud systems. Actually, drilling muds are a key factor in drilling operations. They are used to:

- maintain pressure balance between formation and the borehole;

- lift cuttings to the surface;

- cool and lubricate the drill bit;

- seal permeable formations;

- stabilize the borehole.

Currently, several drilling fluids are emerging. They are mainly of three types: Oil-Based Muds (OBM), Water-Based Muds (WBM) and formate brines. They are briefly discussed at the beginning of the paper with their own pros and cons. The technical difficulty related to HP-HT mud is so significant that alternative systems have to be considered. Therefore new formulations have been jointly developed by IFPEN, Solvay Solexis and Total. The formulations for this application were patented by IFPEN under patent US7858564 [1]. Then the composition was optimized and made subject-matter of an international patent application filed in collaboration with Solvay Specialty Polymers Italy and Total and published as WO2012010530 [2]. They are based on perfluorochemicals whose technology is described in Section 2 of the paper. Final systems have been formulated to cover a density range up to $2.2 \mathrm{SG}$, a thermal stability after prolonged exposure up to $300^{\circ} \mathrm{C}$ and a low viscosity. Their lab preparation and their physicochemical characterization are detailed in the main text of the document.

\section{LITERATURE OVERVIEW OF RECENT HP-HT MUDS}

As mentioned above, there are three main categories of muds used to drill in extreme conditions. Each of them are under constant and advanced research to adapt and improve performance. The articles cited below are some examples of experimental work focusing on the methods to increase the thermal stability of muds. They encompass insightful lab studies and exploratory field cases covering severe HP-HT conditions up to $315^{\circ} \mathrm{C}\left(600^{\circ} \mathrm{F}\right)$ and 2757 bar (40 000 Psi).

\subsection{Oil-Based Muds (OBM)}

Traditionally OBM also called invert emulsions are preferably used to drill deep wells. Actually, their characteristics address technical requirements (good lubricating properties, low fluid loss, adequate filter cake) and they are supposed to show superior temperature stability when compared with WBM. According to Lee et al. [3], most of the invert drilling fluids can handle temperatures up to $205^{\circ} \mathrm{C}\left(400^{\circ} \mathrm{F}\right)$ without significant issues. These authors extended this limit up to $315^{\circ} \mathrm{C}\left(600^{\circ} \mathrm{F}\right)$ by using unspecified products. In the same manner, Moura et al. [4] successfully applied a paraffin-based HP-HT fluid for an offshore exploration well $\left(169^{\circ} \mathrm{C}, 336^{\circ} \mathrm{F}\right)$ in Brazil. The mud was designed to meet the operational requirements by blending it with an unspecified HP-HT stabilizer and organophilic clays as gelling and suspending agents. The same kind of mud containing modified clays was recently employed with standard API barite $\left(\mathrm{BaSO}_{4}\right)$ to drill an exploration well in East Malaysia [5]. Standard barite was introduced as a weighting agent with an appropriate emulsifier package to avoid its sagging. Another option to limit the settling phenomenon is to choose ultra-fine barite [6]. Barite is commonly preferred due to its abundance. Nevertheless, it is criticized due to its high contents in heavy metals such as lead, cadmium, mercury and arsenic [7]. Rehman et al. [8] reported the development of an oil based mud weighted by manganese tetraoxide $\left(\mathrm{Mn}_{3} \mathrm{O}_{4}\right)$ particle instead of barite. They are environmentally friendly (belonging to OCNS group D or E) and advantageously prevent sagging thanks to their inherent sub-micron size. They also exhibit an excellent spherical shape that leads to lower viscosity and reduced abrasion risk.

In sum, the thermal stability of OBM can be substantially improved by the selection of appropriate chemical additives. Anyhow they can be regarded as undesirable from an economic and environmental point of view $[9,10]$. They also present the serious disadvantages of adsorbing a large amount of gas [11] and impairing the logging interpretation [12].

\subsection{Water-Based Muds (WBM)}

Despite their technical performance, OBM may be discarded due to environmental and cost constraints. As a result, operators may have to choose WBM systems. To fill the technical gap between both drilling fluids, new WBM have been designed through extensive studies. Some illustrative examples are given below in the particular case of HP-HT applications. The typical composition of aqueous drilling systems comprises biopolymers (xanthan, scleroglucan gum) or synthetic polymers (polyelectrolytes). High molecular weight polymers are used to give the required rheology while low molecular weight ones are used for fluid loss control. A weighting material is added to adapt density. Tehrani et al. [13] developed a new water based drilling fluid relying on the synergy between the weighting agents (manganese 
tetraoxide or barite) and the selected polymers (modified acrylic polymers and polyvinylpyrolidone). The system showed good thermal stability up to $180^{\circ} \mathrm{C}$. Sun et al. [14] reported the development of a water based organosilicon drilling system that was used in the deep Qingshen gas field at $220^{\circ} \mathrm{C}$. Their formulation includes highly charged ion complexes that adsorb on clay and improve their water retaining capacity. A thick hydration film is formed around clay particles and is said to limit water loss in HT conditions. Recently Elkatatny et al. [15] evaluated a water-based drilling fluid with micronized ilmenite instead of barite with correct drilling properties up to $177^{\circ} \mathrm{C}$.

WBM are not as thermal resistant as oil based ones. Special chemicals may improve their performance so that they can be selected for some severe drilling operations but not all. Most of the water soluble polymers used (biopolymers and polyelectrolytes) are sensible to hydrolysis and thermal degradation. Moreover according to Hassiba and Amani [16] the use of water based drilling fluids may be challenged by the high probability to encounter salt beds in deep wells. Salt contamination may alter their rheological properties and saturated brines may have to be used.

\subsection{Formate Brines}

The use of sodium, potassium and cesium formate brines as drilling and completion HP-HT fluids is relatively new and has been the subject of an abundant literature [17, 18]. The interest for these products is supported by their natural density and their thermal stability. Formate compounds are the salts of formic acid and are easily dissolved in water. Their chemical description can be found in Javora et al. [19]. The exact formulation of a formate mud depends on the target density and does not require the addition of weighting solids. They are compatible with elastomers. In the mid-90s, sodium formate and potassium formate brine became popular, and replaced halide brine, chlorides and bromides. Advantages of formate brine were a less corrosive environment for the metals, a less harmful fluid for personnel and the environment. Cesium formate had difficulty to be introduced into the market due to its price and scarce availability. In the late 90 s oil and gas operators started using the high density Cesium Formate as a completion fluid, replacing Calcium Bromide/Zinc Bromide brines, which were practically banned from North Sea applications.

A review of operator's feedbacks from long term use was recently published by Olvik et al. [20]. It underlines the drilling benefits and their operational success. To reduce the negative impact of cost, formate systems can be recovered at the end of each job and recycled [21]. Despite many advantages, formate muds are challenged because they might affect standard nuclear logging tools [22].

\section{TECHNOLOGY DESCRIPTION OF FLUORINATED POLYMERS AND SURFACTANTS}

\subsection{PFPE Polymers and Surfactants}

PerFluoroPolyEthers (PFPE) are fluorinated fluids that are known for their unique physical and chemical properties. Actually, they exhibit both an excellent thermal stability and a high chemical resistance. They are transparent colourless and odourless oils, which remain liquid in a wide range of temperatures. They are very dense and non-flammable polymers with a low interfacial energy. Due to these numerous advantageous properties, PFPE are used in various high tech applications such as high quality lubrication [23, 24]. PFPE have been commercially available worldwide for long, especially in the form of neutral end-capped fluids. The pioneers of these technological polymers were Solvay Specialty Polymers Italy (Montedison at that time) (Fomblin ${ }^{\circledR}$ PFPE) and $D u$ Pont (Krytox ${ }^{\circledR}$ PFPE) in the 1960s.

Solvay Specialty Polymers Italy is the largest supplier of PFPE fluids with the widest product range in the world. Technology is based on photoxidation of perfluoroalkenes as described in several articles and papers [25-27]. PFPE are divided into two groups of structure: the branched and the linear ones. Their respective structures and preparations are given below.

Branched Fomblin ${ }^{\circledR}$ Y PFPE are prepared by reaction of HexaFluoroPropene (HFP) and oxygen catalyzed by UV light through several steps: the intermediate polyperoxide (I) is then reduced to get rid of the peroxide bonds, leading to a polyether with acid fluoride end groups (II), which are removed by fluorination with elemental fluorine under UV conditions (Fig. 1). In the chain the ratio $p / q$ is about 40 , which means more units $-\mathrm{CF}_{2} \mathrm{CF}\left(\mathrm{CF}_{3}\right) \mathrm{O}-$ than $-\mathrm{CF}_{2} \mathrm{O}$.

Linear Fomblin ${ }^{\circledR} \mathrm{Z}$ are prepared with almost the same process but starting from TetraFluoroEthylene (TFE) (Fig. 2); in this case the ratio $p / q$ is about 0.5-2.

For both processes, the final products can be further fractionated to obtain the suitable grades. Actually, versatility is another attribute of the PFPE compounds, which results in additional benefits to design engineers. The molecular structure of the polymer chain, that is how the $\mathrm{C}, \mathrm{F}, \mathrm{O}$ atoms are linked is the attribute responsible for this broad range of features. Typical properties of PFPE fluids are presented in Table 1. They show the key role played by the structure of the PFPE backbone.

Branched structure (Fomblin ${ }^{\circledR}$ Y PFPE) shows higher values for the $\mathrm{Tg}$ and a greater dependence of the viscosity with the temperature due to the presence of bulky pendant $-\mathrm{CF}_{3}$ groups which causes stiffening of the polymer chain.

On the contrary the linear structure (Fomblin ${ }^{\circledR} \mathrm{Z}$ PFPE) shows a lower decrease in the viscosity with temperature and the lowest values of the pour point due to presence of the $-\mathrm{CF}_{2} \mathrm{O}$ units which increases the degree of flexibility of the molecule, thus showing that the increase in the $\mathrm{O} / \mathrm{C}$ 


$$
\text { (I) }
$$

Figure 1

Preparation of Fomblin ${ }^{\circledR}$ Y.

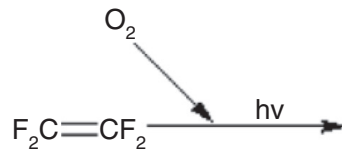

$\mathrm{FOC}-\mathrm{CF}_{2}-\mathrm{O}\left[\left(\mathrm{CF}_{2}-\mathrm{CF}_{2}-\mathrm{O}\right)\left(\mathrm{CF}_{\mathrm{m}}-\mathrm{CF}_{2}-\mathrm{O}-\mathrm{O}\right)\left(\mathrm{CF}_{2}-\mathrm{O}-\mathrm{O}\right)\left(\mathrm{CF}_{2}-\mathrm{O}\right)\right] \mathrm{CF}_{2}-\mathrm{COF}$

(1)

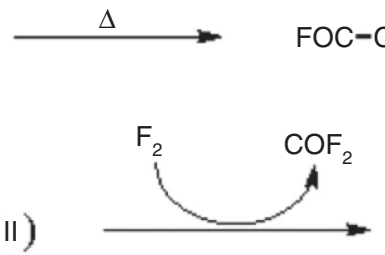

\section{(II)}

$$
\left.\mathrm{CF}_{3}-\mathrm{O}+\mathrm{CF}_{2}-\mathrm{CF}_{2}-\mathrm{O}\right)\left(\mathrm{CF}_{2}-\mathrm{O}\right)_{\mathrm{q}} \mathrm{CF}_{3} \quad \text { Fomblin } \mathrm{Z}
$$

\begin{tabular}{|c|c|c|c|c|c|c|c|c|}
\hline \multirow{2}{*}{$\begin{array}{c}\text { Fomblin }{ }^{\circledR} \\
\text { type }\end{array}$} & \multirow{2}{*}{$\begin{array}{l}\text { Average mol. } \\
\text { weight }\end{array}$} & \multicolumn{3}{|c|}{ Kinematic viscosity } & \multirow{2}{*}{$\begin{array}{l}\text { Viscosity } \\
\text { index }\end{array}$} & \multirow[t]{2}{*}{ Pour point } & \multirow{2}{*}{$\begin{array}{c}\text { Density at } \\
20^{\circ} \mathrm{C}\end{array}$} & \multirow[t]{2}{*}{$\mathrm{Tg}$} \\
\hline & & $20^{\circ} \mathrm{C}$ & $40^{\circ} \mathrm{C}$ & $100^{\circ} \mathrm{C}$ & & & & \\
\hline & $(\mathrm{amu})$ & (cSt) & $(\mathrm{cSt})$ & $(\mathrm{cSt})$ & $(-)$ & $\left({ }^{\circ} \mathrm{C}\right)$ & $\left(\mathrm{g} / \mathrm{cm}^{3}\right)$ & $\left({ }^{\circ} \mathrm{C}\right)$ \\
\hline \multirow[t]{5}{*}{ Y } & 1500 & 38 & 15 & 3.2 & 60 & -58 & 1.87 & \multirow[t]{5}{*}{-57} \\
\hline & 3200 & 250 & 80 & 10 & 108 & -35 & 1.90 & \\
\hline & 4100 & 470 & 147 & 16 & 117 & -35 & 1.97 & \\
\hline & 6250 & 1300 & 345 & 33 & 135 & -30 & 1.91 & \\
\hline & 7250 & 1850 & 510 & 47 & 135 & -25 & 1.92 & \\
\hline \multirow[t]{5}{*}{ Z } & 4000 & 30 & 17 & 5 & 253 & -85 & 1.81 & \multirow[t]{5}{*}{-130} \\
\hline & 8000 & 150 & 85 & 22 & 286 & -75 & 1.83 & \\
\hline & 11000 & 280 & 159 & 45 & 338 & -65 & 1.85 & \\
\hline & 16000 & 550 & 310 & 86 & 343 & -60 & 1.86 & \\
\hline & 23000 & 1300 & 700 & 200 & 375 & -50 & 1.87 & \\
\hline
\end{tabular}

Figure 2

Preparation of Fomblin ${ }^{\circledR}$ Z.

TABLE 1

Properties of PFPE 
ratio is a key parameter for this property. The variation of the viscosity with temperature and pressure for PFPE (Tab. 1) has been extensively studied and reported by many authors [28-32].

The $\mathrm{C}-\mathrm{F}$ chemical bond is the strongest inter-atomic bond found in nature, while at the same time, electronegative fluorine forms a barrier against reagent aggression. The absence of hydrogen also contributes to the stability of PFPE fluids. Therefore, these polymers are chemically inert and resistant to the majority of reagents including mineral acids, alkalis, organic acids and bases, oxidizing and reducing agents and halogens. No reaction or change in the fluid is observed for prolonged exposition to very aggressive chemicals even at high temperatures. They can only be affected by direct contact with strong electropositive metals like $\mathrm{Na}, \mathrm{Al}, \mathrm{Mg}$ or can undergo a decomposition catalyzed by Lewis acids like $\mathrm{AlCl}_{3}$ or $\mathrm{SbF}_{3}$.

\subsection{Functional PFPE and their Applications}

An additional development is the production of functionalized PFPE, in particular the bifunctionalized ones known with the trade name of Fluorolink ${ }^{\circledR}$. Several structures and properties are reported in Table 2.

PFPE structures may be linked to a large variety of functional groups, either reactive or not. This allows providing compounds which perform better in the typical applications of these fluids, and to extend their use to new applications through the proper selection of specific functional groups $[33,34]$. For example functionalized PFPE can be used as surfactants in emulsion and microemulsion technologies [35-37]. These formulations can be employed to cover surface as treatment to impart oleo/hydrophobicity and lubricity to various materials (such as metal, fibers, etc.), or in cosmetic application, etc.

\section{Properties of the selected PFPE for the Mud formulations}

Among the various functionalized PFPE, Table 3 lists the ones that have been selected for the mud formulation. The selection was driven to reach a given range of density, of viscosity and thermal stability, as will be explained in the following section.

\section{HP-HT FLUORINATED MUD}

\subsection{Mud Formulation}

The dense polymer Fomblin ${ }^{\circledR}$ Y04 PFPE $(d=1.9)$ was selected to form the continuous phase of the mud. This choice was based on two additional characteristics:

- a high thermal resistance;

- a moderate viscosity due to its lower molecular weight.

The liquid cannot itself constitute a drilling mud. It is necessary to control the mud during drilling either in

TABLE 2

Typical properties of Fomblin ${ }^{\circledR}$ PFPE derivatives $\mathrm{XCF}_{2} \mathrm{O}-\left[\left(\mathrm{CF}_{2} \mathrm{CF}_{2} \mathrm{O}\right)_{p}\left(\mathrm{CF}_{2} \mathrm{O}\right)_{q}\right]-\mathrm{CF}_{2} \mathrm{X}$

\begin{tabular}{|c|c|c|c|c|}
\hline \multirow[t]{2}{*}{ Trade name } & \multicolumn{4}{|c|}{$\mathrm{X}$} \\
\hline & $-\mathrm{CO}_{2} \mathrm{H}$ & $-\mathrm{CH}_{2}\left(\mathrm{OCH}_{2} \mathrm{CH}_{2}\right)_{n} \mathrm{OH}$ & $-\mathrm{CH}_{2} \mathrm{OH}$ & $-\left(\mathrm{OCH}_{2} \mathrm{CH}_{2}\right)_{n}-\mathrm{OPO}(\mathrm{OH})_{2}$ \\
\hline $\begin{array}{c}\text { Fluorolink }^{\circledR} \\
\text { properties }\end{array}$ & $\mathrm{C} 10$ & $\mathrm{E} 10 \mathrm{H}$ & $\mathrm{D} 10 \mathrm{H}$ & F10 \\
\hline $\mathrm{M}_{\mathrm{w}}(\mathrm{amu})$ & 1500 & 1500 & 1500 & 2000 \\
\hline Fluorine content $(\%)$ & 59 & 57 & 61 & 50 \\
\hline Viscosity (cSt) at $20^{\circ} \mathrm{C}$ & 60 & 115 & 85 & $3 \times 10^{4}-1 \times 10^{5}$ \\
\hline Density $(\mathrm{g} / \mathrm{mL})$ & 1.80 & 1.73 & 1.79 & $1.70-1.80$ \\
\hline Surface tension $($ dyne $/ \mathrm{cm})$ at $20^{\circ} \mathrm{C}$ & 22 & 23 & 24 & n.a \\
\hline Refractive index $n \mathrm{D}_{20}$ & 1.300 & 1.317 & 1.302 & n.a \\
\hline Glass transition $\left(T_{g},{ }^{\circ} \mathrm{C}\right)$ & -110 & -100 & -95 & n.a \\
\hline Vapour pressure $(\mathrm{mmHg})$ at $20^{\circ} \mathrm{C}$ & $2 \times 10^{-5}$ & n.a & $7 \times 10^{-5}$ & n.a \\
\hline Vapour pressure $(\mathrm{mmHg})$ at $100^{\circ} \mathrm{C}$ & $2 \times 10^{-3}$ & n.a & $5 \times 10^{-3}$ & n.a \\
\hline
\end{tabular}


TABLE 3

Properties of selected PFPE

\begin{tabular}{|c|c|c|c|c|c|}
\hline \multirow[t]{2}{*}{ PFPE type } & \multirow{2}{*}{$\begin{array}{l}\text { Average mol. weight } \\
\qquad(\mathrm{amu})\end{array}$} & \multirow{2}{*}{$\begin{array}{l}\text { Density }(\mathrm{g} / \mathrm{mL}) \text { at } \\
20^{\circ} \mathrm{C}\end{array}$} & \multicolumn{3}{|c|}{ Kinematic viscosity (cSt) } \\
\hline & & & $20^{\circ} \mathrm{C}$ & $40^{\circ} \mathrm{C}$ & $100^{\circ} \mathrm{C}$ \\
\hline Fomblin $^{\circledR}$ Y 25 & 3200 & 1.90 & 250 & 80 & 10 \\
\hline Fomblin $^{\circledR}$ Y04 & 1500 & 1.87 & 38 & 15 & 3.2 \\
\hline Fomblin ${ }^{\circledR}$ Y 2045X & 1984 & 1.87 & 62.7 & 25.3 & 4.49 \\
\hline Fluorolink ${ }^{\circledR}$ F10 & 2000 & $1.70-1.80$ & $3 \times 10^{4}-1 \times 10^{5}$ & na & na \\
\hline
\end{tabular}

TABLE 4

Typical composition of HP-HT synthetic mud

\begin{tabular}{c|c|c}
\hline Ingredient & Concentration & Function \\
\hline Fomblin $^{\circledR} \mathrm{Y} 04 \mathrm{PFPE}$ & $73.6 \% \mathrm{vol}$ & Continuous phase \\
\hline Fluorolink $^{\circledR} \mathrm{F} 10 \mathrm{PFPE}$ & $0.4 \% \mathrm{vol}$ & Emulsifier and wetting agent \\
\hline Brine $\left(\mathrm{CaCl}_{2} 300 \mathrm{~g} / \mathrm{L} ; \mathrm{pH}=10\right)$ & $10 \% \mathrm{vol}$ & Internal phase for suspension properties and density decrease \\
\hline Barite $(8 \mu \mathrm{m})$ & $16 \% \mathrm{vol}$ & Weighting agent for suspension properties and density increase \\
\hline
\end{tabular}

increasing its density by adding weighting agents or reducing it by adding a less dense aqueous phase. Therefore one must disperse both phases homogeneously so as to avoid sedimentation. Initial tests showed settling when adding micron sized barite in a PFPE. In order to disperse the weighting agents and the internal aqueous phase within the polymeric liquid, perfluoropolyether surfactants containing different functionalities have been screened. Fluorolink ${ }^{\circledR}$ F10 PFPE was found to be the best candidate. Actually, thanks to two terminal phosphate groups, this product shows good wetting and emulsifying properties. Due to its PFPE composition, it is all the more dense $(d=1.73)$ and thermal resistant. A typical composition of the developed mud is indicated in Table 4.

In order to adapt the formulation to both viscosity and density requirements, and considering the viscosity of the starting PFPE liquid, it is possible to tune the formulation. The volume fraction of weighting agent and of brine are adjusted obeying two constraints. It is necessary to stabilize the weighting agent suspension, helped by the presence of the brine emulsified in the PFPE continuous phase. It is also necessary for the mud to flow properly. Thereby the viscosity must not exceed a certain threshold, thus limiting the volume fraction of all the dispersed objects i.e. weighting agent particles and emulsified brine droplets. Figure 3 illustrates the influence of barite and brine volume fraction upon the density of the mud and its relative viscosity $\eta_{R}=\eta / \eta_{0}$ with $\eta_{0}$ being the viscosity of the initial PFPE liquid.

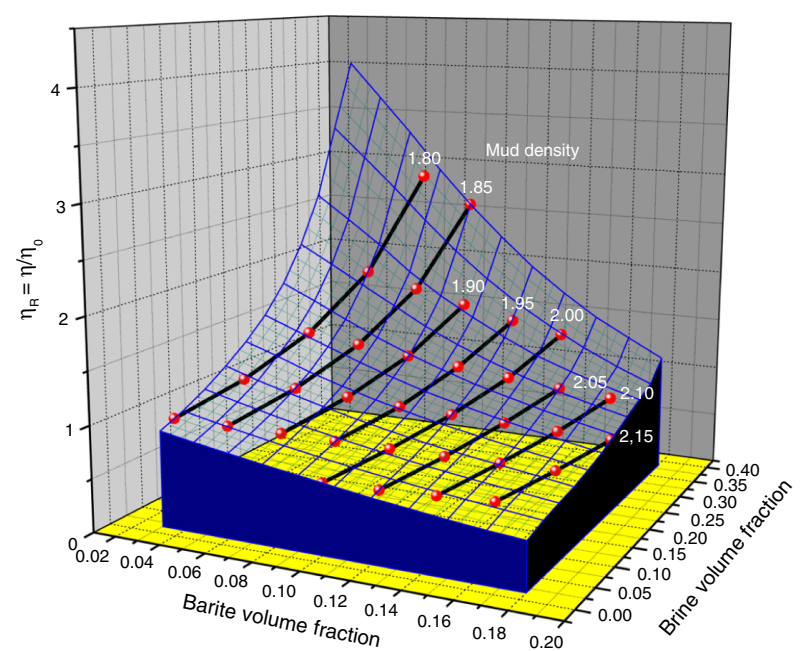

Figure 3

Influence of formulation parameters on both density and relative viscosity of the mud.

The ingredients were mixed using a Ultra Turrax ${ }^{\circledR} \mathrm{T} 25$ homogenizer. To prepare a $200 \mathrm{~mL}$ sample, the ingredients were introduced as follows:

1. introduction of Fomblin ${ }^{\circledR}$ Y04 polymer (279.7 g);

2. introduction of Fluorolink ${ }^{\circledR}$ F10 polymer $(1.384 \mathrm{~g})$ and stirring during 5 minutes;

3. introduction of brine (22.4 g) and stirring during 15 minutes; 


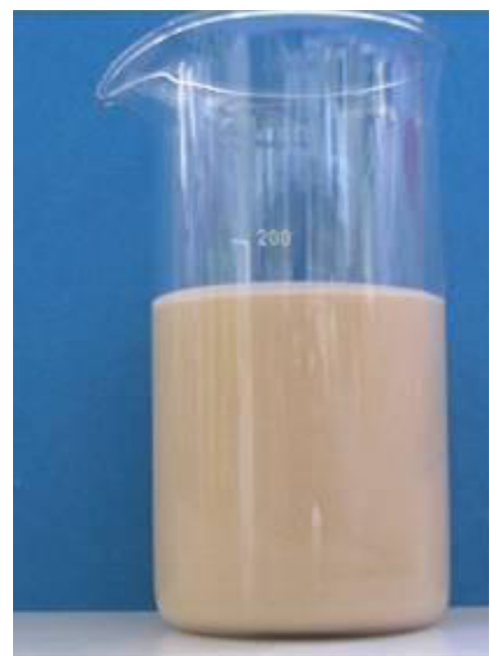

Figure 4

Innovative synthetic fluorinated mud (Fomblin ${ }^{\circledR}$ Y04 and Fluorolink ${ }^{\circledR}$ F10 PFPE).

4. introduction of barite (standard granulometry $8 \mu \mathrm{m}$ ) (134.4 g) and stirring during 15 minutes.

During all the above steps, rotational speed was set at $11000 \mathrm{rpm}$ while temperature was maintained at ambient. The resulting mud can be seen in Figure 4.

The formulation described above underwent a comprehensive battery of laboratory tests to determine its performance. They include:

- a basic characterization at atmospheric pressure (Differential Scanning Calorimetry (DSC), Scanning Electron Microscopy (SEM), viscosity measurements, electrical conductivity and shear resistance);

- tests under HP-HT conditions (viscosity and thermal resistance);

- resistance to influx (liquid hydrocarbons, gas and water).

\subsection{Mud Characterization at Atmospheric Pressure}

\subsubsection{DSC and Cryogenic SEM Analysis}

DSC can be advantageously used to characterize the aqueous internal phase of a drilling fluid. This analytical technique consists of measuring the heat exchanges between the sample and a reference either versus time at constant temperature or versus temperature during a heating or a cooling program. It allows determining the emulsion type, the amount of water, the presence of solute, the stability and the droplet size [38].

The thermograms obtained with the formulated mud are shown in Figure 5. The cooling part comprises a

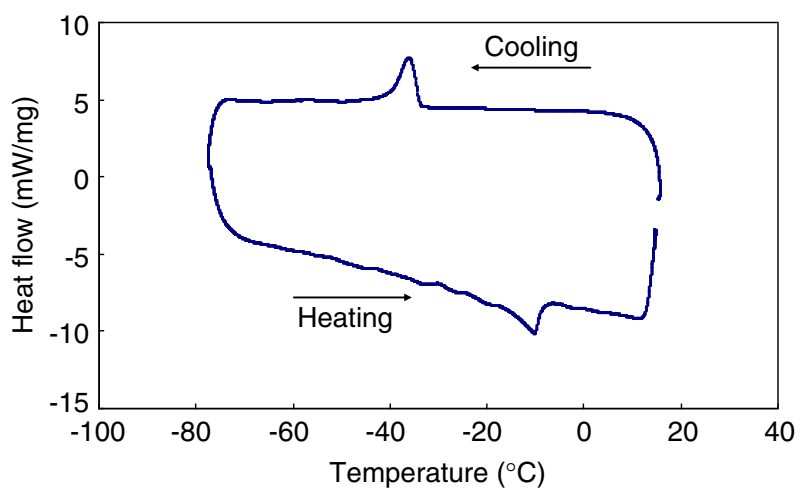

Figure 5

Cooling and heating thermographs of the HP-HT fluorinated mud (Fomblin ${ }^{\circledR}$ Y04 and Fluorolink ${ }^{\circledR}$ F10 PFPE).

single regular exothermic peak at around $-35^{\circ} \mathrm{C}$. This signal is characteristic of a fine and monodisperse emulsion. Actually, according to nucleation theory, the freezing temperature may be correlated to the mean droplet size of the emulsion [38]. The very low peak indicates that the formulated mud comprises micro-sized droplets. During heating, an endothermic peak relates to the progressive melting of the ice. It is observed around $-10^{\circ} \mathrm{C}$, which corresponds to the liquid/salt equilibrium temperature of the brine.

The DSC analysis confirms that the HP-HT fluorinated mud contains the required internal aqueous phase. Moreover, it can be noted that this phase is dispersed in micron size droplets, that favors the emulsion stability.

To cross check the DSC characterization, microscopic analysis were performed with cryogenic SEM on the fluorinated mud. The SEM results confirmed the small size of emulsion and the good dispersion of mineral particles. In addition, SEM provided the elemental composition of the sample. Figure 6 is an example of barium (barite particles) and chlorine (brine) analysis which confirms the size of the particles and good morphology of the mud.

\subsubsection{Rheological Characterization}

Rheological characterization was carried out using the controlled stress rheometer Haake 150 with a $40 \mathrm{~mm}$ sanded plate geometry. The flow curves showed that the HP-HT fluorinated mud has the required rheological properties of a drilling mud:

- a yield stress;

- a shear thinning behaviour. 
a)

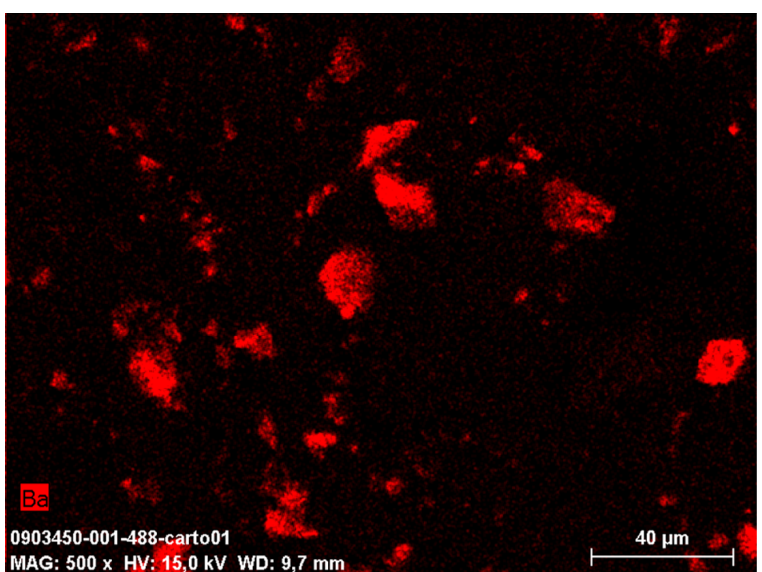

b)

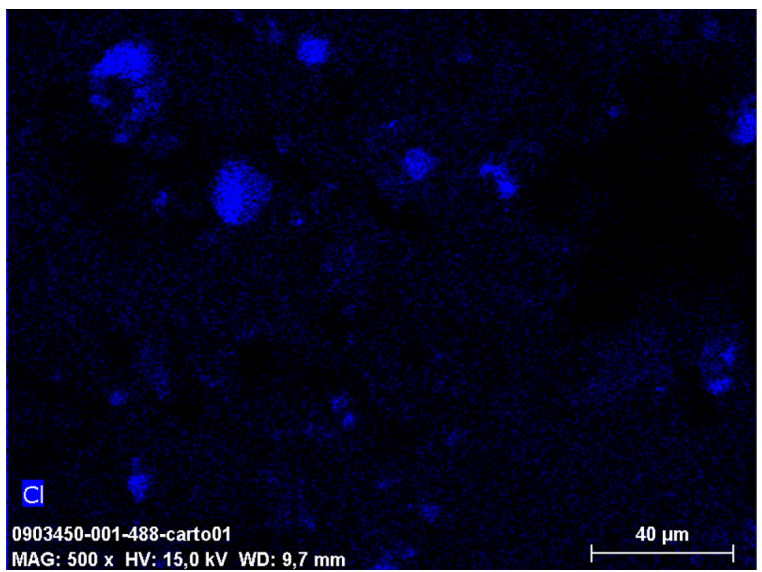

Figure 6

Cryo-SEM elemental analysis of the HP-HT fluorinated mud (Fomblin ${ }^{\circledR}$ Y04 and Fluorolink ${ }^{\circledR}$ F10 PFPE); a) barium, b) chlorine.
TABLE 5

Rheological properties of the HP-HT fluorinated mud

\begin{tabular}{c|c|c|c|c}
\hline & $\tau_{y 0}(\mathrm{~Pa})$ & $k$ & $n$ & $\eta(\mathrm{cp})$ at $500 \mathrm{~s}^{-1}$ \\
\hline $20^{\circ} \mathrm{C}$ & 3 & 0.44 & 0.92 & 280 \\
\hline $30^{\circ} \mathrm{C}$ & 2.3 & 0.26 & 0.93 & 180 \\
\hline $50^{\circ} \mathrm{C}$ & 1.9 & 0.14 & 0.93 & 93 \\
\hline $80^{\circ} \mathrm{C}$ & 1.6 & 0.07 & 0.93 & 50 \\
\hline
\end{tabular}

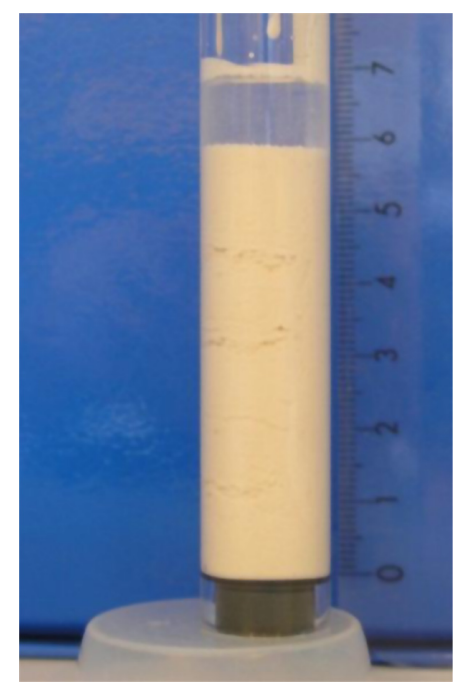

Figure 7

HP-HT synthetic mud (Fomblin ${ }^{\circledR}$ Y04 and Fluorolink ${ }^{\circledR}$ F10 PFPE) ( $1 / 3$ standard and $2 / 3$ fine barite) after complete settling.
The responses have been fitted with the Herschel-Bulkley model:

$$
\tau=\tau_{y 0}+k \dot{\gamma}^{n}
$$

with: $\tau$, shear stress $(\mathrm{Pa}) ; \dot{\gamma}$, shear rate $\left(\mathrm{s}^{-1}\right) ; \tau_{y 0}$, yield shear stress $(\mathrm{Pa}) ; k$, consistency; $n$, power law exponent.

The model coefficients for different temperatures are presented in Table 5. The viscosity measured at around $500 \mathrm{~s}^{-1}$ is also indicated. When plotted as a function of temperature, it obeys the Arrhenius law with an activation energy equal to $24 \mathrm{~kJ} / \mathrm{mol}$. This result shows that the viscosity of the fluorinated HP-HT mud has a classical thermal dependency.

\subsubsection{Settling Tests}

The settling tests consist of monitoring the extent of phase separation with time. It is carried out with a Turbiscan ${ }^{\mathrm{TM}} \mathrm{LAB}$ apparatus that acquires transmission and backscattering data every $40 \mu \mathrm{m}$ while moving along the $55 \mathrm{~mm}$ cell height. The acquisition along the product is then repeated with a programmable frequency to obtain product profiles and reveal the stability or instability of the product. The extent of phase separation in static conditions was estimated at around $45 \%$. It can be mentioned that the supernatant phase is clear and transparent. IR and DSC analysis have been performed on it. They reveal that it does not contain any water nor solid particles.

The previous settling tests have been repeated on a reformulated mud. It contains alternative weight materials composed of $1 / 3$ of standard barite $(8 \mu \mathrm{m})$ and $2 / 3$ of finegrind barite $(2 \mu \mathrm{m})$ in weight. The results show that the partial addition of fine barite limits the extent of the settling to $15 \%$ after 24 hours (Fig. 7).

Rheological measurements were performed on the mud containing partly fine barite. Its viscosity is only slightly increased compared to that of the initial mud. The addition 


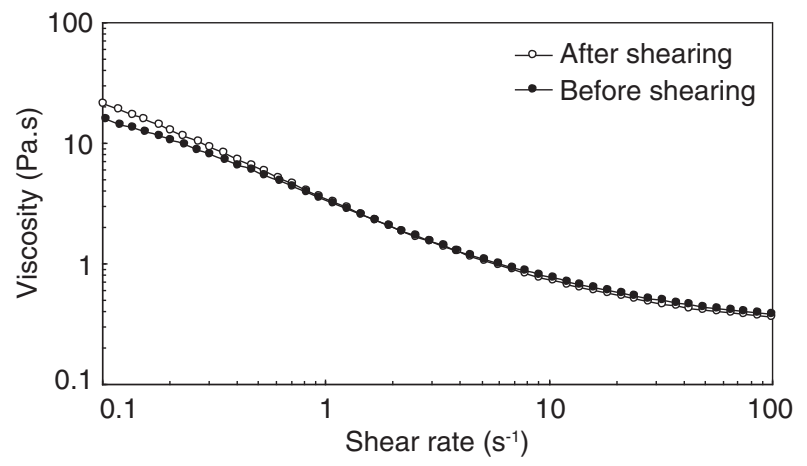

Figure 8

Viscosity at $20^{\circ} \mathrm{C}$ of the HP-HT fluorinated mud (Fomblin ${ }^{\circledR}$ Y04 and Fluorolink ${ }^{\circledR}$ F10 PFPE) before and after shearing.

of fine barite improves the settling properties of the mud without being detrimental to its flow behaviour.

\subsubsection{Electric Conductivity}

Electric conductivity of the HP-HT fluorinated mud (Fomblin ${ }^{\circledR}$ Y04 and Fluorolink ${ }^{\circledR}$ F10 PFPE) has been measured using Metrohm 712 conductimeter with an open geometry measurement cell. A value of $210 \mu \mathrm{S} / \mathrm{m}$ was found at ambient temperature. According to Sawdon et al. [39], this value is within the desirable range for electrical logging operations $\left(10-10^{3} \mu \mathrm{S} / \mathrm{m}\right)$.

\subsubsection{Shear Resistance}

During drilling operations, the mud must sustain strong mechanical solicitations. In order to quantify the mechanical resistance of the new synthetic mud, the formulation was sheared with a Ultra Turrax ${ }^{\circledR}$ T25 homogenizer during 4 hours at $11000 \mathrm{rpm}$. The flow curve of the sheared sample was measured at $20^{\circ} \mathrm{C}$ and compared to the one of the unsheared blank (Fig. 8). These curves are exactly the same, showing that the mud is resistant to mechanical shearing.

\subsection{Mud Characterization under HP-HT Conditions and Thermal Resistance}

\subsubsection{Rheological Behavior under HP-HT Conditions}

The rheological behavior of a first fluorinated mud was characterized under HP-HT conditions. This mud had the same composition as the one given in Table 4, except it contains Fomblin ${ }^{\circledR}$ Y25 PFPE as base polymer. The tests were performed on a Fann 70 rheometer with temperature ranging from 75 to $200^{\circ} \mathrm{C}$ and pressure ranging from 1 to 1330 bar. The resulting flow curves showed that the mud is
Newtonian, with a viscosity remaining constant as the shear rate changes. When plotted as a function of pressure, viscosity increases exponentially obeying Barus' law:

$$
\kappa=\frac{d \ln \eta}{d P}
$$

$\kappa$ is the piezoviscous coefficient which value strongly depends upon temperature. It can be mentioned that pressure effect on viscosity strongly diminishes at high temperature. Actually, in deep conditions, viscosity will be mostly governed by temperature.

The HP-HT rheology of a second fluorinated PFPE mud (Fomblin ${ }^{\circledR}$ Y04 and Fluorolink ${ }^{\circledR}$ F10 PFPE) was also characterized. Results are given in Table 6. They were entered into a proprietary simulator and Equivalent Circulating Densities (ECD) were calculated (Fig. 9) with the following conditions:

- drilling fluid: $2.12 \mathrm{sg}$,

- bit depth: $7019 \mathrm{~m}$,

- flow rate: $1000 \mathrm{~L} / \mathrm{min}$,

- pipe rotation: $110 \mathrm{rpm}$,

- rate of penetration: $2 \mathrm{~m} / \mathrm{h}$,

- frac pressure: $2.29 \mathrm{sg}$ EMW (Equivalent Mud Weight) at $6250 \mathrm{mTVD}$ (True Vertical Depth).

The results show that a drilling fluid designed with a base fluid Fomblin ${ }^{\circledR}$ Y04 PFPE is compatible with drilling operations in an HP-HT type well.

\subsubsection{Thermal Resistance}

In order to test their thermal resistance, several PFPE mud samples were introduced into sealed gold tubes placed inside an autoclave (Fig. 10). This set up enabled to heat the samples at temperatures up to $300^{\circ} \mathrm{C}$ during 24 hours, with an external pressure of 100 bar.

After heating at $250^{\circ} \mathrm{C}$ during 24 hours, the phase separation appears with the same extent as the one previously determined at $25^{\circ} \mathrm{C}$ with a Turbiscan ${ }^{\mathrm{TM}}$ apparatus. A gentle stirring is enough to disperse the settled phase (Fig. 11).

Once the mud is homogenised, flow curves were measured and compared to the original ones (Fig. 12). They almost superimpose, which demonstrates the thermal stability of the fluorinated muds.

To confirm the thermal resistance, microscopic analysis were performed with cryogenic SEM on the heated fluorinated mud (Fomblin ${ }^{\circledR}$ Y04 and Fluorolink ${ }^{\circledR}$ F10 PFPE). The morphology they revealed is the same as the original sample (Fig. 13). Despite having undertaken a severe heating, samples still contain well dispersed water droplets and barite particles.

The two previous fluorinated muds have been tested in more severe thermal conditions: they have been introduced in sealed gold tubes and placed in an autoclave at $300^{\circ} \mathrm{C}$ for 24 hours. Pictures of the resulting products are shown 
TABLE 6

HP-HT rheology of PFPE mud (Fomblin ${ }^{\circledR}$ Y04 and Fluorolink ${ }^{\circledR}$ F10 PFPE)

\begin{tabular}{|c|c|c|c|c|c|c|c|c|c|c|c|c|c|c|c|}
\hline & & \multicolumn{14}{|c|}{ FANN 75 readings } \\
\hline \multicolumn{2}{|c|}{ Shear rate } & Pression & 0 & 0 & 0 & 3000 & 6000 & 6000 & 9000 & 9000 & 12000 & 12000 & 15000 & 12000 & 15000 \\
\hline rpm & $\mathrm{s}^{-1}$ & $\begin{array}{c}\text { Temperature } \\
\left({ }^{\circ} \mathrm{C}\right)\end{array}$ & 25 & 50 & 65 & 80 & 80 & 120 & 120 & 155 & 155 & 180 & 180 & 200 & 200 \\
\hline 600 & 1022 & & 300 & 179 & 113 & 186 & 221 & 145 & 213 & 100 & 191 & 101 & 138 & 61 & 86 \\
\hline 300 & 511 & & 246 & 83 & 70 & 104 & 146 & 81 & 104 & 68 & 102 & 65 & 93 & 32 & 41 \\
\hline 200 & 341 & & 192 & 58 & 55 & 78 & 110 & 63 & 79 & 55 & 79 & 53 & 72 & 25 & 29 \\
\hline 100 & 170 & & 105 & 37 & 37 & 49 & 68 & 43 & 51 & 40 & 51 & 38 & 49 & 18 & 21 \\
\hline 60 & 102 & & 56 & 29 & 29 & 36 & 49 & 33 & 38 & 33 & 39 & 31 & 39 & 17 & 18 \\
\hline 30 & 51 & & 32 & 23 & 24 & 27 & 34 & 27 & 30 & 29 & 30 & 27 & 31 & 15 & 16 \\
\hline 6 & 10 & & 11 & 9 & 14 & 16 & 21 & 23 & 23 & 19 & 20 & 19 & 20 & 12 & 15 \\
\hline 3 & 5 & & 8 & 7 & 13 & 14 & 18 & 18 & 22 & 15 & 18 & 10 & 14 & 10 & 10 \\
\hline
\end{tabular}

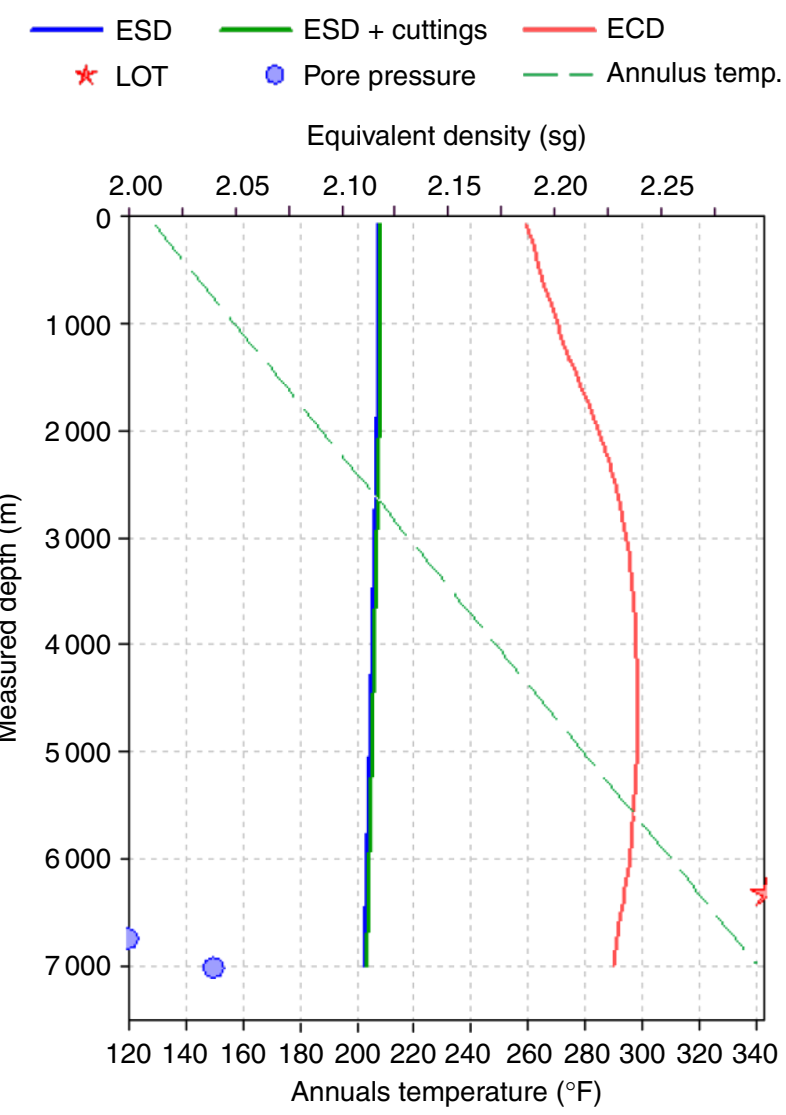

Figure 9

ECD simulation for PFPE mud (Fomblin ${ }^{\circledR}$ Y04 and Fluorolink ${ }^{\circledR}$ F10 PFPE).

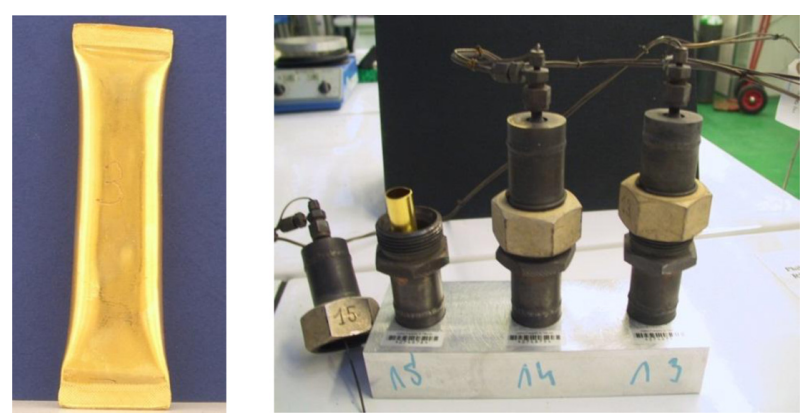

Figure 10

Gold tube and autoclave used to heat the PFPE mud.

in Figure 14. The two muds prepared with PFPE keep their fluidity despite the harshness of the thermal treatment.

\subsection{Resistance to Formation Fluid Influxes}

In case of unexpected fluid influxes in a well or "kick", mixing between mud and formation fluids can take place and affect mud properties. Fluorinated muds present the significant advantage of not adsorbing either hydrocarbon or aqueous fluids, thus preventing the mud from being impacted. This immiscibility between mud and formation fluids also favours kick detection. These important assets are illustrated in the next paragraphs successively detailing the resistance of fluorinated muds to hydrocarbon, gas and water influxes. 


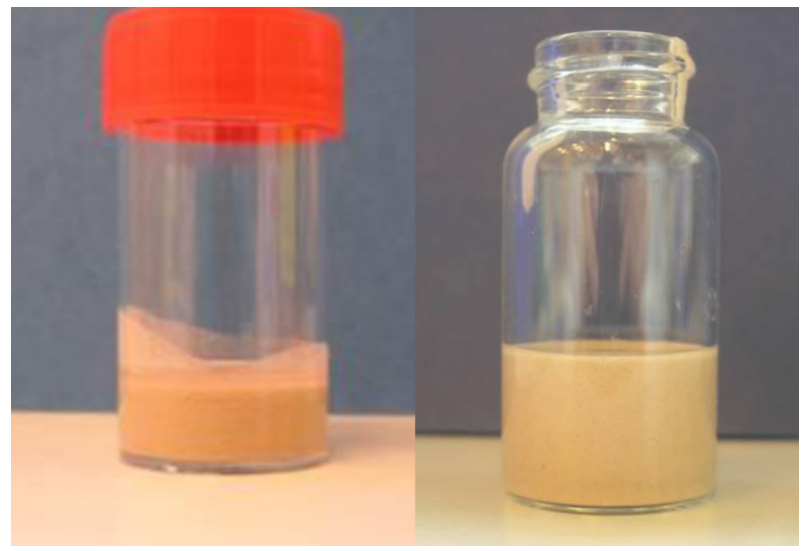

Figure 11

HP-HT Fluorinated mud (Fomblin ${ }^{\circledR}$ Y04 and Fluorolink ${ }^{\circledR}$ F10 PFPE) after having been exposed to $250^{\circ} \mathrm{C}$ during 24 hours.
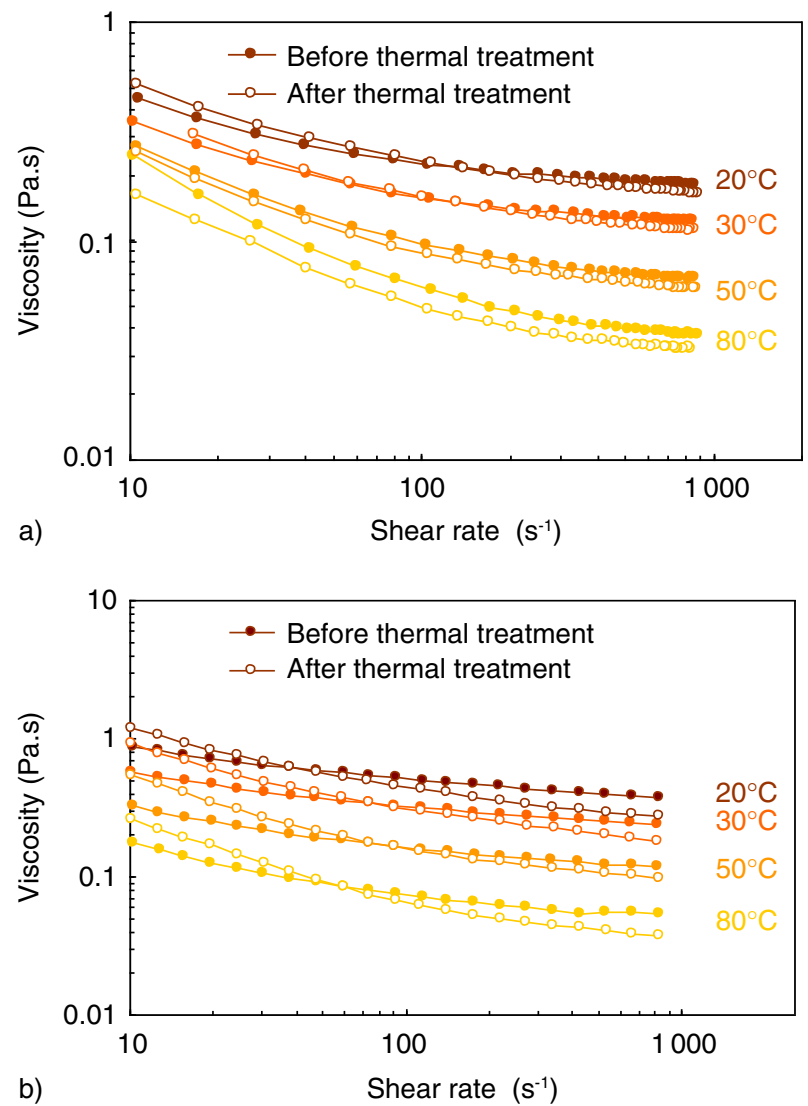

Figure 12

Flow curves of the HP-HT fluorinated mud a) Fomblin ${ }^{\circledR}$ Y04 and Fluorolink ${ }^{\circledR}$ F10 PFPE; b) Fomblin ${ }^{\circledR} 2045$ X-Fluorolink ${ }^{\circledR}$ F10 PFPE before and after thermal treatment at $250^{\circ} \mathrm{C}$ for 24 hours.

\subsubsection{Resistance to Hydrocarbons Influx}

The resistance to hydrocarbon influxes has been evaluated by introducing into the fluorinated mud (Y04-F10) two different light oil cuts: a naphtha (saturated) and a kerosene (aromatic). Mixing was applied with the Ultra Turrax ${ }^{\circledR} \mathrm{T} 25$ homogeniser, set at $11000 \mathrm{rpm}$ for 5 minutes. The mixture is composed of $10 \mathrm{~mL}$ of mud and $10 \mathrm{~mL}$ of cut. The response of the mud against naphtha and kerosene is exactly the same: as soon as the stirring is stopped, the two phases quickly separate with the mud going down and the cut going up. Both phases have been analyzed to check if they had been contaminated during mixing:

- an IR spectrum was performed on the supernatant (cut);

- a DSC and IR analysis were carried out on the bottom (mud).

On the IR spectra of kerosene and naphtha after contact with the mud no fingerprints of $\mathrm{O}-\mathrm{H}$ and C-F bonds could be identified demonstrating that the cut does not contain any water nor PFPE polymer from the mud. As an example in Figure 15 IR spectrum of kerosene after contact is reported.

The DSC analysis that was carried out on the mud after mixing with kerosene or naphtha shows that water droplets are still dispersed in the mud. Crystallization peaks below $-20^{\circ} \mathrm{C}$ were obtained, meaning that no coalescence took place and that the droplet diameter is still sub micronic. This result confirms the stability of the emulsion.

The results of IR spectra on the mud (Fomblin ${ }^{\circledR}$ Y04 and Fluorolink $^{\circledR}$ F10 PFPE) after mixing with kerosene or naphtha do not reveal any $\mathrm{C}-\mathrm{H}$ fingerprint showing that the mud does not retain hydrocarbons from the cut.

\subsubsection{Resistance to Gas Influx}

In case of a kick with hydrocarbon gases, the mixture between mud and influx can lead to very complex and multiphase flow. Actually, temperature and pressure will govern the thermodynamic equilibrium between dissolved and free gas. Below the bubble point, gas bubbles can expand and lead to violent flashing. The foamy behaviour of the fluorinated mud (Fomblin ${ }^{\circledR}$ Y04 and Fluorolink ${ }^{\circledR}$ F10 PFPE) has been studied in the pressure cell of the controlled stress rheometer AR2000 from TA Instruments.

The test comprises two successive steps:

1. the first step consists of dissolving methane in the sample under sufficient pressure (1 $000 \mathrm{psi})$ and enough shearing $\left(500 \mathrm{~s}^{-1}\right)$. This step is maintained until the system reaches the equilibrium prevailed by Henry's law i.e. saturation;

2. during the second step, the system is suddenly depressurized from the applied saturation pressure (1 $000 \mathrm{psi}$ ) to atmospheric pressure, while viscosity is continuously measured. 


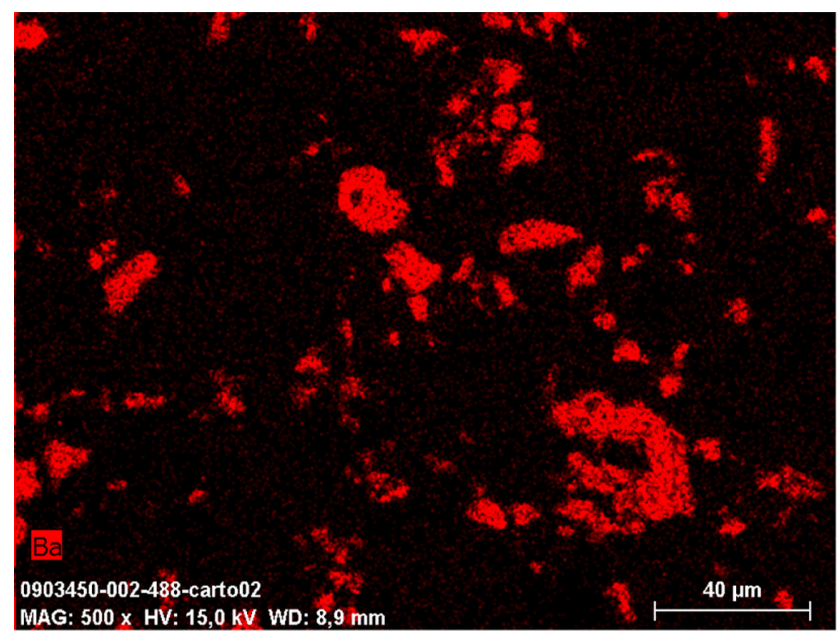

a)

Figure 13

Cryo-SEM elemental analysis of the HP-HT fluorinated mud; a) barium; b) chlorine.

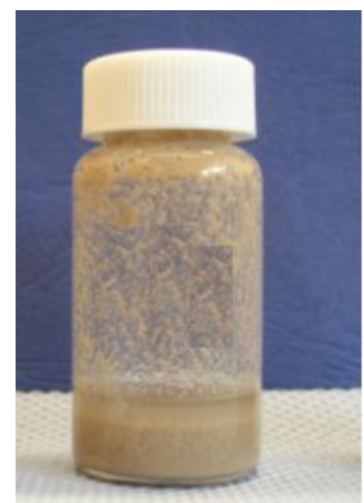

a)

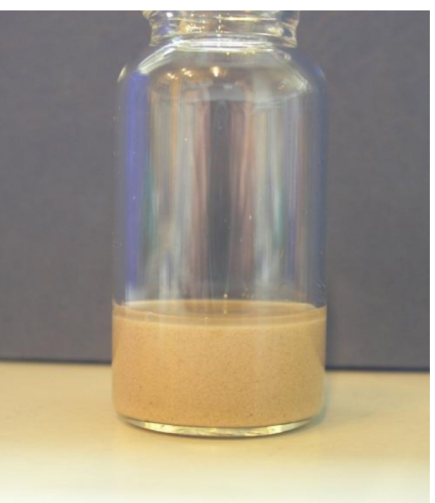

b)

\section{Figure 14}

HP-HT Fluorinated muds after having been exposed to $300^{\circ} \mathrm{C}$ during 24 hours; a) Fomblin ${ }^{\circledR}$ Y04 and Fluorolink ${ }^{\circledR}$ F10 PFPE; b) mud Fomblin ${ }^{\circledR}$ 2045X-Fluorolink ${ }^{\circledR}$ F10 PFPE.

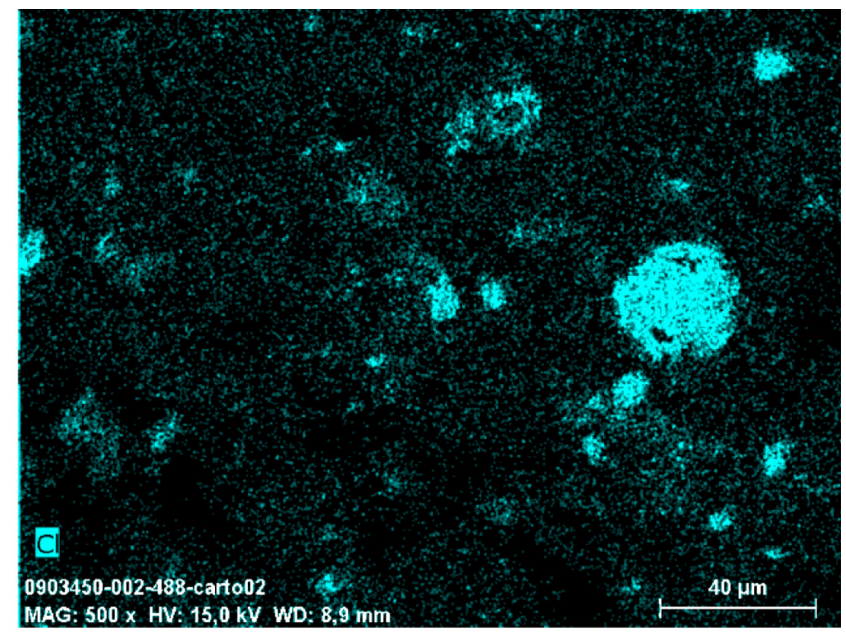

b) 


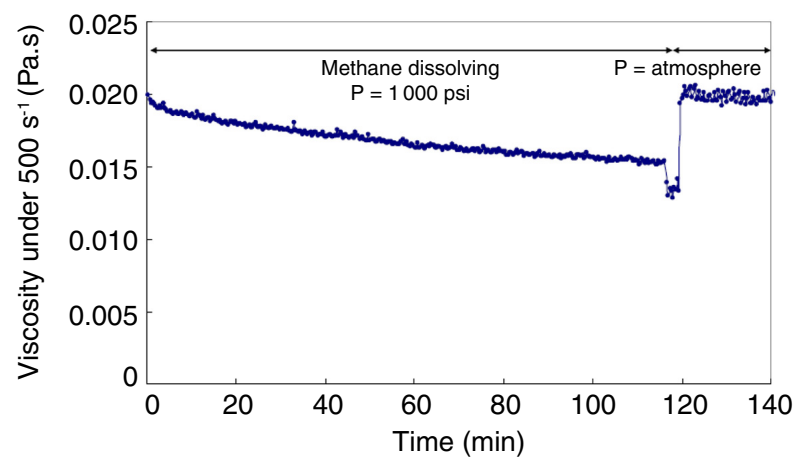

Figure 16

Foamy behaviour of fluorinated mud (Fomblin ${ }^{\circledR}$ Y04 and Fluorolink ${ }^{\circledR}$ F10 PFPE) with methane.

resulting thermographs crystallization were observed, demonstrating that the mud still contains emulsified water. During the mixing, the water droplets did not escape from the mud to the free aqueous phase.

\section{CONCLUSIONS}

PFPE muds appear as a real breakthrough for HP-HT drilling challenges. They meet the following specified requirements:

- limited amounts of weighting materials,

- versatility of density,

- immiscibility with reservoir fluids (water, gas, hydrocarbons),

- low viscosity,

- excellent thermal stability (up to $300^{\circ} \mathrm{C}$ ),

- environmentally safe,

- easy to formulate.

Fomblin ${ }^{\circledR}$ Y PFPE and Flurolink ${ }^{\circledR}$ F10 PFPE have been registered by CEFAS (Centre for Environment Fisheries and Aquaculture Science) in the UK. They have been classified using test protocols approved by OSPAR with the Offshore Chemicals Notification Scheme (OCNS). Both products were ranked into the group $\mathrm{D}$ under the Non-Charm classification model, A representing the highest environmental hazard and $\mathrm{E}$ the lowest.

To our knowledge, none of the known drilling fluids (OBM, WBM, formate brines) can achieve such properties.

Significant challenges remain to face. Actually, due to the particular composition of the fluorous muds, conventional drilling fluid additives are not efficient. For example, the developed muds show excessive fluid loss. There is thus a need to develop new chemistries for additives, compatible with PFPE, such as new filtration control agents. Successful tests have been obtained recently with PFPE particles [40]. The further study of the structure-property relationships could help to optimize formulations. As PFPE can be quite easily functionalized and tailored for given applications, we are confident with the future development of such fluorous muds.

\section{REFERENCES}

1 Pasquier D., Driancourt A., Audibert A. (2010) Well fluid comprising a fluorinated liquid phase, US7858564.

2 Naegel M., Gregoire M., Pasquier D., Henaut I., Rovinetti S., Meunier V. (2012) Drilling fluid composition, WO2012010530.

3 Lee J., Shadravan A., Young S. (2012) Rheological properties of invert emulsion drilling fluid under extreme HPHT conditions, SPE Paper 151 413, Drilling Conference and Exhibition, San Diego, California, USA, 6-8 March.

4 Moura E., Cockeis E., Lucas G., Fontes M., Pessanha R., Aragao A. (2011) Paraffin-based HP/HT fluids technology applied successfully in exploration well in Jequitinhonha basin offshore, Brazil, 10th Offshore Mediterranean Conference and Exhibition, Ravenna, Italy, 23-25 March.

5 Syazwan M., Yap Y., Umar L., Pepple M. (2013) Successful HP/HT drilling through innovative practices: sharing a case study of a deep HP/HT well, SPE Paper 166110, Annual Technical Conference and Exhibition, New-Orleans, Louisiana, USA, 30 Sept.-2 Oct.

6 Taugbol K., Fimreite G., Prebensen O., Svanes K., Omland T., Svela P., Breivik D. (2005) Development and field testing of a unique HT/HP oil-based drilling fluid with minimum rheology and maximum sag stability, SPE Paper 96285, Offshore Europe, Aberdeen, Scotland, UK, 6-9 Sept.

7 Rae P., di Lullo G., Atikah A. (2001) Towards environmentally friendly additives for well completion and stimulation operations, SPE Paper 68651, Asia Pacific Oil \& Gas Conference and Exhibition, Jakarta, Indonesia.

8 Relman A., Al Moajil A.M., Nasr-El-Din H.A., Al Bagoury M., Steel C.D. (2012) Environmentally friendly dispersants for high temperature invert-emulsion drilling fluids weighted by manganese tetraoxide, SPE Paper 153646, Latin American and Carribean Petroleum Engineering Conference, Mexico City, Mexico 16-18 April.

9 Davies J.M., Addy J.M., Blackman R.A., Blanchards J.R., Ferbrache J.E., Moore D.C., Somerville H.J., Whitebread A., Wilkinson T. (1984) Environmental effects of the use of oilbased drilling muds in the North Sea, Marine Pollution Bulletin 15, 10, 363-370.

10 Elward-Berry J., Darby J.B. (1998) Rheologically stable, nontoxic, high temperature, water-based drilling fluid, Oceanographic Literature Review 45, 1, 180.

11 Downs J.D., Blaszczynski M., Turner J., Harris M. (2006) Drilling and completing difficult HP/HT wells with the aid of cesium formate brines - a performance review, IADC/SPE Drilling Conference, Miami, Florida, USA, 21-23 Feb.

12 Francis P.A., Eigner M.R.P., Patey I.T.M. (1995) Visualisation of drilling induced formation damage mechanisms using reservoir conditions core flood testing, SPE Paper 30088, SPE European Formation Damage Conference, The Hague, Netherlands, 15-16 May. 
13 Tehrani M.A., Popplestone A., Guarneri A., Carminati S. (2007) Water-based drilling fluid for HP/HT applications, SPE Paper 105485, International Symposium on oilfield chemistry, Houston, Texas, USA, 28 Feb.-2 March.

14 Sun Y., Zhang Y., Zhao J. (2009) Organosilicon drilling fluid system for HT deep gas well, SPE Paper 118852, SPE Western regional meeting, San Jose, California, USA, 24-26 March.

15 Elkatatny S.M., Nasr-El-Din H.A., Al-Bagoury M. (2013) IPTC 16983, International Petroleum Technology Conference, Beijing, China, 26-28 March.

16 Hassiba K., Amani M. (2012) Salinity effect on the rheological properties of water based mud under high pressures and high temperatures of deep wells, SPE Paper 163315, SPE Kuwait International Petroleum Conference and Exhibition, Kuwait city, Kuwait, 10-12 Dec.

17 Dows J.D. (1993) Formate brines: novel drilling and completion fluids for demanding environments, SPE Paper 25177, International Symposium on oilfield chemistry, New-Orleans, Louisiana, USA, 2-5 March.

18 Gallino G., Guarneri A., Maglione R., Nunzi P., Xiao L. (1997) New formulations of potassium acetate and potassium formate polymer muds greatly improve drilling and waste disposal operations in south Italy, SPE Paper 37471, SPE Production Operations Symposium, Oklahoma city, USA, 9-11 March.

19 Javora P.H., Ke M., Stevens R.F., Berry S.L. (2003) The chemistry of formate brines at downhole conditions, SPE Paper 80211, International Symposium on oilfield chemistry, Houston, Texas, USA, 5-7 Feb.

20 Olsvik G., Howard S., Downs J. (2013) The long-term production performance of deep HPHT gas condensate fields developed using formate brines, SPE Paper 165151, SPE European Formation Damage Conference, Noordwijk, Netherlands, 6-7 June.

21 Simpson M.A., Al-Reda S., Foreman D., Guzman J., Al-Fawzy M., Vice P. (2009) Application and recycling of sodium and potassium formate brine drilling fluids for Ghawar field HT gas wells, OTC 19801, Offshore Technology Conference, Houston, Texas, USA, 4-7 May.

22 Moake G.L. (2012) Formate mud effects on density logs, SPWLA 53 ${ }^{\text {rd }}$ Annual Logging Symposium, Cartagena, Colombia, 16-20 June.

23 Jones W.R. Jr (1993) NASA Technical Memorandum 106275, The properties of PFPEs used for space applications.

24 Caporiccio G., Flabbi L., Marchionni G., Viola G.T. (1989) The properties and applications of perfluoropolyether lubricants, J. Synth. Lubr. 6, 133.

25 Marchionni G., Ajroldi G., Pezzin G. (1996) Comprehensive polymer science, Eds Pergamon press, Oxford, Chap. 9, p. 347.
26 Sianesi D., Marchionni G., De Pasquale R.J. (1994) Organofluorine Chemistry: Principles and Commercial Applications, Ed. Plenum, New-York, Chap. 20, p. 431.

27 Marchionni G., Srinivasan P. (1992) Synthesis, properties and commercial applications, Fluoropolymer Conference, Manchester, 6-8 Jan.

28 Sianesi D., Zamboni V., Fontanelli R., Binaghi M. (1971) Perfluoropolyethers: their physical properties and behavior at high and low temperatures, Wear 18, 85-100.

29 Marchionni G., Ajroldi G., Cinquina P., Tampellini E., Pezzin G. (1990) Physical properties of perfluoropolyethers: dependence on composition and molecular weight, Polym. Eng. Sci. 30, 829.

30 Tanaka Y., Noijri N., Ohta K., Kubota H., Makita T. (1989) Density and viscosity of linear perfluoropolyethers under high pressures, Int. J. Thermophys. 10, 857-870.

31 Wolf B.A., Klimiuk M., Cantow M.J.R. (1989) PVT data of poly(perfluoroether)s and how they govern the flow behavior, J. Phys. Chem. 93, 2672-2675.

32 Cantow M.J.R., Barral E.M., Wolf B.A., Geerissen H. (1987) Temperature and pressure dependence of the viscosities of perfluoropolyether fluids, J. Polym. Sci. Polym. Phys. Ed. 25, 603-609.

33 Tonelli C., Gavezotti P., Strepparola E. (1999) Linear perfluoropolyether difunctional oligomers: chemistry, properties and applications, Journal Fluorine Chemistry 96, 51-70.

34 Tonelli C., di Meo A., Fontana S., Russo A. (2002) Perfluoropolyether functional oligomers: unusual reactivity in organic chemistry, Journal Fluorine Chemistry 118, 107-121.

35 Caporiccio G., Burzio F., Carniselli G., Biancardi V. (1984) Some physicochemical properties of perfluoropolyether surfactants, Journal Colloid Interface Science 98, 1, 202-209.

36 Visca M., Chittofrati A. (1991) Microemulsions containing perfluoropolyether, US 4990283.

37 Brunetta F., Pantini G. (1994). Stable emulsions of perfluoropolyethers and fat substances and process for preparing them, US 5368847.

38 Dalmazzone C., Noïk C., Clausse D. (2009) Application of DSC for Emulsified System Characterization, Oil \& Gas Science and Technology - Rev. IFP 64, 5, 543-555.

39 Sawdon C., Tehrani M., Craddock P., Lawson A. (2004). Electrically conductive non-aqueous wellbore fluids, US 6770603.

40 Galindo K.A., Deville J.P., Espagne B.J.L., Pasquier D., Henaut I., Rovinetti S. (2013) Fluorous-Based Drilling Fluid for UltraHigh-Temperature Wells, SPE Paper 166126, SPE Annual Technical Conference and Exhibition, New-Orleans, Louisiana, USA, 30 Sept.-2 Oct.

Manuscript accepted in October 2014 Published online in January 2015 